\title{
Peptides Released from Foremilk and Hindmilk Proteins by Breast Milk Proteases Are Highly Similar
}

\author{
Søren D. Nielsen, Robert L. Beverly and David C. Dallas* \\ Nutrition Program, School of Biological and Population Health Sciences, College of Public Health and Human Sciences, \\ Oregon State University, Corvallis, OR, United States
}

Human milk contains active proteases that initiate hydrolysis of milk proteins within the mammary gland. Milk expressed at the beginning of feeding is known as foremilk and that at the end of feeding is known as hindmilk. As hindmilk contains higher fat, vitamins $A$ and $E$, and higher calories than foremilk, feeding only hindmilk initially and reserving foremilk for later are practiced in some neonatal intensive care units. This study investigated the difference in peptide profiles, predicted milk protease activities, and bioactive peptides between foremilk and hindmilk. Bioactive peptides are short fragments of proteins that influence biological processes. Four mothers pumped $10 \mathrm{~mL}$ of their

OPEN ACCESS

Edited by:

Aifric O'Sullivan,

University College Dublin,

Ireland

Reviewed by:

Stefano Sforza,

Università degli Studi di

Parma, Italy

Emma Louise Feeney, University College Dublin,

Ireland

*Correspondence: David C. Dallas

dave.dallas@oregonstate.edu

Specialty section: This article was submitted to Nutrition Methodology, a section of the journal

Frontiers in Nutrition

Received: 17 August 2017 Accepted: 19 October 2017 Published: 02 November 2017

Citation:

Nielsen SD, Beverly RL and Dallas DC (2017) Peptides

Released from Foremilk and Hindmilk Proteins by Breast Milk Proteases Are Highly Similar.

Front. Nutr. 4:54. doi: 10.3389/fnut.2017.00054 foremilk and $10 \mathrm{~mL}$ of their hindmilk into iced containers prepared with antiproteases and the samples were immediately frozen. The peptide profile of each sample was analyzed by liquid chromatography nano-electrospray ionization Orbitrap Fusion tandem mass spectrometry. Peptide abundance (sum of ion intensities) and count (number of unique peptide sequences) in each milk sample were determined from this analysis. The specific enzymes that participated in peptide release were predicted based on the amino acids positioned at each cleavage site. Peptide bioactivity was predicted based on homology to a known functional peptide database and two bioactivity prediction algorithms. Hindmilk contained a higher count of peptides than foremilk. The higher number of unique peptide sequences in hindmilk was related to hydrolysis of $\beta$-casein,

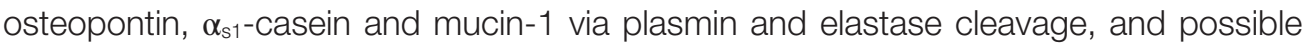
aminopeptidase and carboxypeptidase activities. Though hindmilk contained a greater number of peptides than foremilk, the overall peptide abundance did not differ and most of the total peptide abundance derived from peptide sequences that were present in both milk types. The presence of higher numbers of predicted bioactive peptides in the hindmilk could indicate that the practice of providing hindmilk rather than foremilk to premature infants could positively impact health outcomes; however, as there are few differences in overall peptide abundance, the overall effect is likely limited.

Keywords: peptides, human, mother's milk, casein, whey, bioactive, protease

\section{INTRODUCTION}

Human milk has evolved to match the newborn infant's nutritional needs and is highly important for the growth and development of the neonate. Besides providing the infant with nutrients, human milk contains many bioactive components that are preformed prior to expression, such as immunoglobulins, hormones, and growth factors, that contribute to the infant's development. 
In addition to proteins that are bioactive intact, milk proteins contain encrypted sequences released upon proteolysis that exert an array of functions, often different from that of the parent protein.

Breastfeeding has been associated with a number of health benefits for the human infant, such as reduced risk of nonspecific gastroenteritis, severe lower respiratory tract infections, type 1 and 2 diabetes, and necrotizing enterocolitis (1). Though the mechanisms for these associations are not entirely clear, they are likely due to the coordinated effects of the bioactive molecules in milk. Milk protein-derived peptides have an array of identified functions that may benefit the infant, including antimicrobial, immunomodulatory, angiotensin-converting enzyme (ACE)- and dipeptidyl peptidase IV inhibitory, and opioid activity (2-4).

Our recently constructed online database of all known bioactive milk peptides (5) contains hundreds of peptides that have been experimentally confirmed as bioactive. Many of these peptides were identified from human milk samples after in vitro digestion with gastric enzymes (6-8) or selected for testing by applying predictive models to the entire milk protein sequences $(9,10)$.

Previous literature demonstrated that human and bovine milks contain an array of proteases and protease inhibitors [reviewed in Ref. (11)]. Our recent work confirmed that native proteases exist in milk, including (from highest to lowest concentration) carboxypeptidase B2, plasmin, kallikrein, elastase, thrombin, cathepsin D, and cytosol aminopeptidase. Besides cathepsin $\mathrm{D}$, which is inactive at milk $\mathrm{pH}$, all of these milk proteases are in active forms within milk (12). The presence of numerous proteases in milk is proposed to lead to hydrolysis of the milk proteins (11-13). In previous studies, peptides derived from the natural proteolysis of milk proteins have been identified ( 7 , 14-17). This intra-mammary gland proteolytic activity can occur in the time between milk expressions for feeding the neonate, in which milk is secreted from mammary epithelial cells and stored in alveoli and lactiferous ducts until expression (18). The native proteolytic activity of milk may release peptides that are relevant to the developing infant or the mammary gland itself.

Previous studies have demonstrated differences in the composition of milk expressed at the beginning of feeding (foremilk) and end of feeding (hindmilk). Foremilk has been defined as the first 2-3 min after flow initiation ("letdown") and hindmilk is defined as the remainder of milk obtained until complete breast emptying $(19,20)$. Hindmilk has a higher fat concentration, energy density, and concentration of vitamins A and E (19, 21, 22). These previous studies were performed with sample sizes of between 15 and 24 mothers. Though there is little significant difference in protein content between foremilk and hindmilk (23), hindmilk resides longer within the mammary gland in the presence of the native milk proteases than foremilk, thus potentially affecting the peptide composition of the milk. Such changes could alter the availability of bioactive peptides for the infant.

Based on previous results showing differences in the nutritional composition between foremilk and hindmilk, and due to the activity of native milk proteases, we hypothesized that the count and abundance of milk peptides between foremilk and hindmilk would be different as well. Foremilk and hindmilk from four term mothers were analyzed via mass spectrometrybased peptidomics and examined for differences in peptides, predicted protease activity, and predicted bioactive peptides.

\section{MATERIALS AND METHODS}

\section{Participants and Samples}

The study was approved by the Institutional Review Board at Oregon State University, and informed consent was obtained from all mothers. Human foremilk and hindmilk samples were collected from four mothers (2-4 months of lactation). All mothers gave birth to term infants. Mothers with any signs of clinical mastitis and current antibiotic usage were excluded from the study. Before pumping, mothers thoroughly washed their hands and cleansed their nipples with a moist single-use paper towel. Breasts were pumped using a hospital-grade Medela Symphony electrical pump (Salem, OR, USA). All parts that contacted the mother or her milk were single use. Mothers were instructed to pump the first $10 \mathrm{~mL}$ of milk (foremilk) into an 80-mL breastmilk collection container (6109S-100; Medela) premarked at the $10-\mathrm{mL}$ line. The container was prepared with protease inhibitor solution and held on ice [1 tablet of a protease inhibitor cocktail (cOmplete ${ }^{\mathrm{TM}}$ mini protease inhibitor cocktail tablets, 11836153001; Roche, Basel, Switzerland) added to $1 \mathrm{~mL}$ of MilliQ water, according to the manufacturer's instructions]. The exact components of the antiprotease mixture are not disclosed; however, it inhibits a wide array of serine, cysteine, and metalloproteases as well as calpains. When the level of milk reached $10 \mathrm{~mL}$, the mother immediately stopped pumping and passed the milk bottle to the researchers. The milk was immediately mixed well by gentle rocking, and divided into five $2-\mathrm{mL}$ aliquots in 2-mL Eppendorf tubes and placed on dry ice within $1 \mathrm{~min}$ after expression. The mother kept pumping the milk into a second container until the flow rate dropped and the mother felt her breast was near empty [in all cases, later than 3 min after flow initiation, the standard definition for hindmilk (19)]. The mother then pumped $10 \mathrm{~mL}$ of hindmilk into a third container, which was handled as described for foremilk. After removing aliquots, the samples were immediately transported on dry ice to storage in $\mathrm{a}-80^{\circ} \mathrm{C}$ freezer within $30 \mathrm{~min}$ of expression. Milks were stored at $-80^{\circ} \mathrm{C}$ for a maximum of three weeks prior to peptidomic analyses.

\section{Sample Preparation}

Aliquots of each milk sample (four foremilk and four hindmilk samples) were thawed on ice for approximately $30 \mathrm{~min}$ before removing the milk fat by centrifugation $(3,000 \times g$ for $10 \mathrm{~min}$ at $\left.4^{\circ} \mathrm{C}\right)$. The infranates $(400 \mu \mathrm{L})$ were collected by pipette. Milk proteins were precipitated from the skimmed milk by adding $400 \mu \mathrm{L}$ of $24 \%$ trichloroacetic acid $(240 \mathrm{~g} / \mathrm{L})$ followed by agitation of a vortex mixer for $10 \mathrm{~s}$. Samples were centrifuged at $4,000 \times g$ for $10 \mathrm{~min}$ at $4^{\circ} \mathrm{C}$, and $600 \mu \mathrm{L}$ of the supernatant containing the peptides were collected.

To remove trichloroacetic acid, salts, oligosaccharides and lactose from the peptide solution, the peptides were extracted via 
C18 reverse-phase preparative chromatography in 96-well plates (Glygen, Columbia, MD, USA). In general, unless otherwise noted, the volume of solution used in the different steps was $200 \mu \mathrm{L}$ and the centrifuge parameters were $2,000 \times g$ for $1 \mathrm{~min}$ at $4^{\circ} \mathrm{C}$. Each step was repeated three times. To activate the $\mathrm{C} 18$ reversephase columns, 99\% acetonitrile (ACN), $0.1 \%$ trifluoroacetic acid (TFA) solution was added. Columns were equilibrated with $1 \%$ ACN, $0.1 \%$ TFA before each sample was added to a separate well and centrifuged. This step was repeated two more times to load the total sample volume $(600 \mu \mathrm{L})$ onto the column. The columns were washed with $1 \% \mathrm{ACN}, 0.1 \%$ TFA to remove trichloroacetic acid, salts, lactose and oligosaccharides. The peptides were eluted with $80 \%$ ACN, $0.1 \%$ TFA. The peptide solutions were lyophilized using a freeze dry system (Labconco FreeZone 4.5 L, Kansas City, MO, USA). After freeze drying the samples, they were rehydrated in $40 \mu \mathrm{L}$ of $0.1 \% \mathrm{FA}$ in water.

\section{Protein Determination}

The bicinchoninic acid assay for protein (ThermoFisher Scientific, Waltham, MA, USA) - conducted as described by the manufacturer with bovine serum albumin as reference protein-was used for determination of the protein/peptide concentration (24).

\section{Liquid Chromatography Nano- Electrospray Ionization Mass Spectrometry Peptide Profiling}

Liquid chromatography separation was performed on a Waters Nano Acquity UHPLC (Waters Corporation, Milford, MA, USA) with a nanospray source. Peptides were loaded $(1 \mu \mathrm{L})$ onto a $180 \mu \mathrm{m} \times 20 \mathrm{~mm}, 5-\mu \mathrm{m}$ bead $2 \mathrm{G}$ nanoAcquity UPLC trap column (reverse-phase) for enrichment and online desalting and then onto a $100 \mu \mathrm{m} \times 100 \mathrm{~mm}, 1.7-\mu \mathrm{m}$ bead Acquity UPLC Peptide BEH C18 column (Waters) connected to a Orbitrap Fusion Lumos (Thermo Scientific). To reduce the effects of analysis variation, the samples were loaded alternating between the two milk types. Peptides were eluted using a gradient of $0.1 \%$ FA in water (A) and $99.9 \% \mathrm{ACN}, 0.1 \% \mathrm{FA}(\mathrm{B})$ with a flow rate of $500 \mathrm{~nL} / \mathrm{min}$. The $120-\mathrm{min}$ gradient consisted of $3-10 \%$ solvent B over $3 \mathrm{~min}, 10-30 \%$ solvent B over $99 \mathrm{~min}, 30-90 \%$ solvent B over $3 \mathrm{~min}, 90 \%$ solvent B for $4 \mathrm{~min}, 90-3 \%$ solvent B over $1 \mathrm{~min}$ then finally held at $3 \%$ solvent B for $10 \mathrm{~min}$. Each sample analysis was followed by a 30-min column wash.

Spectra were collected in positive ionization mode with an electrospray voltage of $2,400 \mathrm{~V}$. The mass spectrometer was set to scan masses between 400 and $1,500 \mathrm{~m} / z$ at a resolution of $120 \mathrm{~K}$. The automatic gain control target was set to $4.0 \times 10^{5}$, with a maximum injection time of $50 \mathrm{~ms}$. The fragmentation mode was set to collision-induced dissociation and the collision energy was 35\%. The mass spectrometer cycle time was $3 \mathrm{~s}$, with data-dependent analysis and automated precursor peak selection. Precursors were excluded ( $10 \mathrm{ppm}$ mass error) after one fragmentation and held for $1 \mathrm{~min}$. Precursor ions were selected for fragmentation based on the following criteria: most intense peaks, ion intensity threshold $5.0 \times 10^{3}$ and charge state $2-7$. Fragments were detected with ion trap automatic scan range.
Spectra were analyzed by database searching in Thermo Proteome Discoverer (v2.1.0.81). The data were searched against an in-house human milk protein sequence database. Phosphorylation of serine and threonine and oxidation of methionine was allowed as potential modifications. Peptides identified with high confidence $(P<0.01)$ were accepted. Each peptide sequence with multiple modifications was grouped into a single entry for counts. Counts measured the number of unique peptide sequences identified in a sample. Abundance measured the area under the curve of the eluted peak (ion intensity). As the abundance measurement is based on relative ion intensity, it is only an approximation of the amount of peptides in the samples.

Peptides were mapped to their parent protein sequence of $\beta$-casein, osteopontin, and $\alpha_{s 1}$-casein using an in-house tool (PepEx) (15), which can be accessed at http://mbpdb.nws.oregonstate.edu/pepex/. PepEx gives a visualization of the position of peptides identified by totaling the abundance or count of each amino acid from the peptidomic data.

\section{Bioactive Peptide Identification and Prediction}

The identified peptides in human milk samples were investigated for literature-identified bioactive peptides using our recently created Milk Bioactive Peptide Database (MBPDB) (5), which is a comprehensive database of all milk protein-derived bioactive peptides reported in literature and can be accessed at http://mbpdb.nws.oregonstate.edu/. The search performed was conducted as a sequence search, which searches for bioactive peptides matching the input peptide sequence. To predict the bioactive potential of each identified peptide, we used two online prediction tools-CAMPR3 (antimicrobial prediction) (25) and Peptide Ranker (general bioactivity prediction) (26). The CAMPR3 prediction was conducted by inputting the list of identified peptide sequences and searching for antimicrobial potential with four algorithms (SVM, random forest, artificial neural network, and discriminant analysis). For general bioactivity (Peptide Ranker), peptide sequences were input with no further options available and results were scores from 0 to 1 for each peptide with 1 being most likely to be bioactive.

\section{Enzyme Prediction}

To investigate which proteases were involved in cleaving human milk proteins into peptides, three approaches were used. In Proteome Discoverer, peptides were identified with annotated sequences. With this information, Excel was used to determine the count and abundance of which amino acids were present in the $\mathrm{P} 1$ and $\mathrm{P} 1^{\prime}$ positions of the $\mathrm{N}$ - and $\mathrm{C}$-termini of each peptide identified. The cleavage specificity of known milk proteases were mapped to these amino acids for visual interpretation in the figures [based on the most abundant amino acids listed at P1 and $\mathrm{P}^{\prime}$ ' on Merops (27)] and included elastase (MEROPS ID: S01.131), kallikrein 6 (KLK 6) (MEROPS ID: S01.236), kallikrein 11 (KLK 11) (MEROPS ID: S01.257), plasmin (MEROPS ID: S01.233), and thrombin (MEROPS ID: S01.217). To determine which peptides were possibly released by exopeptidase activity, 
the number of peptides that differed from a related sequence by one amino acid at either the $\mathrm{N}$ - or C-termini was counted.

To predict which enzymes were active in milk using more complex cleavage specificity by accounting for amino acids from $\mathrm{P} 4$ to $\mathrm{P} 2$ ' and $\mathrm{P} 4$ to P4', the two online predictors EnzymePredictor and Proteasix, respectively, were used.

EnzymePredictor ${ }^{1}$ required input of the peptide amino acid sequences and their associated protein ID as found at uniprot. org (28). This information is used to identify the amino acids located at the P4, P3, P2, P1, P1', and P2' positions of both the $\mathrm{N}$ - and $\mathrm{C}$-terminal cleavage sites of each peptide. Based on this information and the cleavage specificity patterns of the selected proteases, EnzymePredictor predicts which enzyme could yield each peptide. For each protease identified, EnzymePredictor provides the count of N-terminal-, C-terminal- and total cleavages assigned to each enzyme, the number of times an enzyme could have cleaved within all the protein sequences in the library of proteins observed and the odds ratio (comparing the number of predicted cleavages based on sequence alone with the actual peptide cleavages assigned to each protease).

Proteasix ${ }^{2}$ predicted which enzymes were involved in the peptide cleavage sites using amino acid cleavage patterns from Merops (27). Proteasix required the input protein ID and start and stop amino acid number of the peptide within the protein. The enzymes searched against were plasmin (PLG), neutrophil elastase (ELANE), thrombin (F2), KLK 6, and KLK 11 based on the amino acids positioned from $\mathrm{P} 4$ to $\mathrm{P} 4^{\prime}$ at the cleavage site. Predicted and observed cleavages were combined in the result output.

\section{Statistical Analysis}

Analyses were carried out using the statistical program RStudio version 1.0.136. A linear mixed model with Tukey's HSD post hoc

${ }^{1}$ http://bioware.ucd.ie/ enzpred/Enzpred.php.

${ }^{2} \mathrm{http}: / /$ proteasix.org/. test was used to adjust for multiple comparisons between foremilk and hindmilk. Significant difference was defined as $P<0.05$. Results are presented as least square mean \pm SE. For individual comparison of the peptide abundance in foremilk compared to hindmilk, a two-tailed pairwise $t$-test was conducted using the $t$-test function in Excel.

\section{RESULTS}

\section{Peptide Profile}

Protein concentration in breast milk was determined by the bicinchoninic acid assay and was not significantly different between the foremilk $(10.2 \pm 0.4 \mathrm{mg} / \mathrm{mL})$ and hindmilk $(9.5 \pm 0.4 \mathrm{mg} / \mathrm{mL})$. The coefficient of variation for total protein concentration was $8.6 \%$. On average, $474 \pm 14$ peptides were identified in the foremilk and $591 \pm 14$ identified in the hindmilk (Figure 1A). Significantly more peptides were identified in the hindmilk than the foremilk $(P=0.0106)$. A total of $370.3 \pm 11.7$ peptides were found in both the foremilk and hindmilk of each mother and comprised $98.3 \pm 1.1 \%$ of the foremilk peptide abundance and $96.7 \pm 1.1 \%$ of the hindmilk peptide abundance. Of these peptides, 135 peptides deriving from 10 different proteins were identified in both fore and hindmilk of all four mothers (Tables 1-3). These accounted for $91.3 \pm 3.5$ and $86.8 \pm 3.5 \%$ of the total abundance of peptides in foremilk and hindmilk, respectively. The abundance of all peptides in each sample were not significantly different between foremilk and hindmilk $\left(5.9 \times 10^{11} \pm 7.1 \times 10^{10}\right.$ and $7.1 \times 10^{11} \pm 7.1 \times 10^{10}$, respectively; Figure 1B). However, of all the peptides identified, 36 were found to be significantly more abundant in hindmilk than foremilk $(P<0.05$; Table 4$)$. No peptides were significantly more abundant in foremilk than hindmilk.

The peptides derived on average from $24.5 \pm 0.8$ proteins in the foremilk and $27.0 \pm 0.8$ proteins in the hindmilk $(P=0.127)$. In total, peptides from 42 proteins were identified. The peptides derived mostly from $\beta$-casein $(51.1 \pm 7.4 \%$ of total abundance),
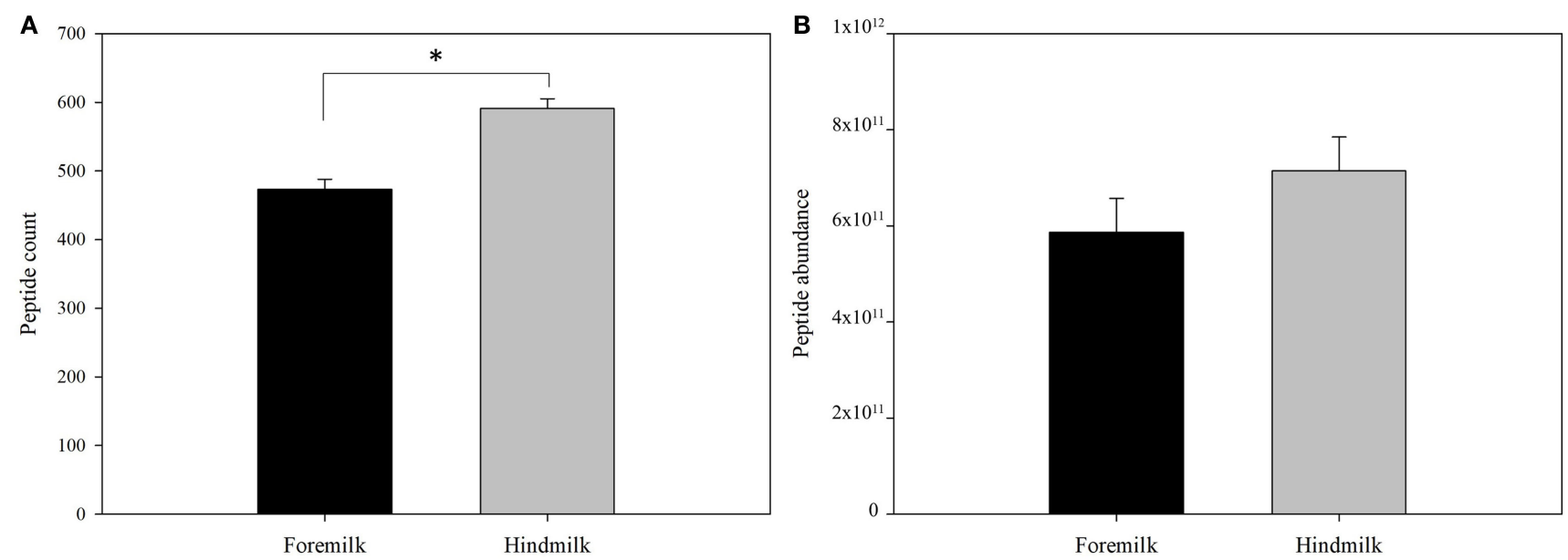

FIGURE 1 | Total count (A) and abundance (B) of peptides in foremilk and hindmilk. Results are shown as least square mean \pm SE, $n=4$. Asterisks $\left(^{\star}\right)$ indicate significant differences between foremilk and hindmilk $(P<0.05)$. 
TABLE 1 | Peptides derived from $\alpha_{\mathrm{s} 1}$-casein identified in both foremilk and hindmilk samples from all four mothers.

\begin{tabular}{lcc}
\hline Sequence & Start & Stop \\
\hline RPKLPLRYPE & 16 & 25 \\
RPKLPLRYPERLQNPSESSEPIPLESREEYMNGMN & 16 & 50 \\
RPKLPLRYPERLQNPSESSEPIPLESREEYMNGMNR & 16 & 51 \\
YPERLQNPSESSEPIPLESREEYMNGMN & 23 & 50 \\
RLQNPSESSEPIPLESREE & 26 & 44 \\
RLQNPSESSEPIPLESREEY & 26 & 45 \\
RLQNPSESSEPIPLESREEYMNGM & 26 & 49 \\
RLQNPSESSEPIPLESREEYMNGMN & 26 & 50 \\
RLQNPSESSEPIPLESREEYMNGMNR & 26 & 51 \\
LQNPSESSEPIPLESREEYMNGMN & 27 & 50 \\
NPSESSEPIPLESRE & 29 & 43 \\
NPSESSEPIPLESREEYMNGMN & 29 & 50 \\
EPIPLESREEYMNGMNR & 35 & 51 \\
QRNILREKQTDEIKDTR & 52 & 68 \\
RNILREKQTDEIKDTR & 53 & 68 \\
NILREKQTDEIKDT & 54 & 67 \\
NILREKQTDEIKDTR & 54 & 68 \\
\hline
\end{tabular}

"Start" and "stop" indicate the amino acid numbers for the beginning and end of the peptide within the protein sequence (counting the signal sequence).

osteopontin $(31.1 \pm 11.3 \%), \alpha_{\mathrm{s} 1}$-casein $(11.1 \pm 6.1 \%)$, polymeric immunoglobulin receptor $(3.2 \pm 1.4 \%)$, butyrophilin $(2.6 \pm 2.6 \%)$, mucin-1 $(0.3 \pm 0.3 \%)$, bile salt-activated lipase $(0.1 \pm 0.08 \%)$, fibrinogen $\alpha$-chain $(0.08 \pm 0.07 \%)$, and perilipin- 2 $(0.1 \pm 0.1 \%)$. The remaining proteins accounted for $0.3 \pm 0.1 \%$ of total abundance. The highest number of peptides derived from $\beta$-casein, and more peptides were identified from $\beta$-casein in hindmilk (199 \pm 9 peptides) than in foremilk (149 \pm 9 peptides) $(P=0.0312)$, although there was no difference in abundance (Figure 2). The second highest number of milk peptides derived from osteopontin. The count of peptides from osteopontin was higher in hindmilk $(121 \pm 2)$ than foremilk $(111 \pm 2)(P=0.0334)$, but there was no difference in abundance. $\alpha_{s 1}$-Casein-derived peptides were higher in hindmilk than foremilk by count $(65 \pm 1$ vs. $53 \pm 1, P=0.00184)$ and tended to be higher in hindmilk than foremilk by abundance $(P=0.0587)$. For mucin- 1 , both the count $(P=0.0138)$ and abundance $(P=0.0129)$ of peptides were higher in hindmilk than foremilk ( $19 \pm 1$ vs. $12 \pm 1$ for count). Peptides deriving from polymeric immunoglobulin receptor and butyrophilin did not differ in count or abundance between foremilk and hindmilk.

The total number of peptides deriving from $\beta$-casein, osteopontin, and $\alpha_{\mathrm{s} 1}$-casein accounted for most of the peptide abundance- $-94.7 \pm 1.2$ and $91.9 \pm 1.2 \%$ in foremilk and hindmilk, respectively. The peptides identified in foremilk and hindmilk were highly similar, shown for these three proteins from which most peptides were derived (Figures 3-5).

\section{Protease Activity Prediction}

To identify which of the known proteases in milk were involved in digestion of the foremilk and hindmilk, we used three bioinformatic approaches. Each peptide typically has two cleavage sites, unless the $\mathrm{N}$-terminus or $\mathrm{C}$-terminus of the peptide coincides with the N-terminus or C-terminus of the protein sequence. Foremilk and hindmilk had $879 \pm 27$ and 1,101 \pm 27 cleavage sites, respectively.
TABLE 2 | Peptides derived from $\beta$-casein identified in both foremilk and hindmilk samples from all four mothers.

\begin{tabular}{|c|c|c|}
\hline Sequence & Start & Stop \\
\hline RETIESLSSSEESITEY & 16 & 32 \\
\hline RETIESLSSSEESITEYK & 16 & 33 \\
\hline RETIESLSSSEESITEYKQ & 16 & 34 \\
\hline RETIESLSSSEESITEYKQK & 16 & 35 \\
\hline RETIESLSSSEESITEYKQKVE & 16 & 37 \\
\hline RETIESLSSSEESITEYKQKVEK & 16 & 38 \\
\hline RETIESLSSSEESITEYKQKVEKVK & 16 & 40 \\
\hline RETIESLSSSEESITEYKQKVEKVKHEDQQQGEDEHQD & 16 & 53 \\
\hline RETIESLSSSEESITEYKQKVEKVKHEDQQQGEDEHQDK & 16 & 54 \\
\hline RETIESLSSSEESITEYKQKVEKVKHEDQQQGEDEHQDKIYP & 16 & 57 \\
\hline ETIESLSSSEESITE & 17 & 31 \\
\hline ETIESLSSSEESITEYK & 17 & 33 \\
\hline ETIESLSSSEESITEYKQ & 17 & 34 \\
\hline ETIESLSSSEESITEYKQK & 17 & 35 \\
\hline ETIESLSSSEESITEYKQKVEK & 17 & 38 \\
\hline ETIESLSSSEESITEYKQKVEKVK & 17 & 40 \\
\hline TIESLSSSEESITEYK & 18 & 33 \\
\hline TIESLSSSEESITEYKQKVEK & 18 & 38 \\
\hline IESLSSSEESITEYK & 19 & 33 \\
\hline IESLSSSEESITEYKQKVEK & 19 & 38 \\
\hline ESLSSSEESITE & 20 & 31 \\
\hline ESLSSSEESITEYK & 20 & 33 \\
\hline SLSSSEESITE & 21 & 31 \\
\hline SLSSSEESITEYK & 21 & 33 \\
\hline SLSSSEESITEYKQKVEK & 21 & 38 \\
\hline LSSSEESITEYK & 22 & 33 \\
\hline SSSEESITEYK & 23 & 33 \\
\hline SSSEESITEYKQKVEK & 23 & 38 \\
\hline SSEESITEYK & 24 & 33 \\
\hline SSEESITEYKQKVEK & 24 & 38 \\
\hline SEESITEYK & 25 & 33 \\
\hline EESITEYK & 26 & 33 \\
\hline QKVEKVKHEDQQQGEDEHQDKIYP & 34 & 57 \\
\hline KVEKVKHEDQQQGEDEHQDKIYP & 35 & 57 \\
\hline KVEKVKHEDQQQGEDEHQDKIYPS & 35 & 58 \\
\hline VEKVKHEDQQQGEDEHQDKIYPS & 36 & 58 \\
\hline VKHEDQQQGEDEHQDKIYP & 39 & 57 \\
\hline VKHEDQQQGEDEHQDKIYPS & 39 & 58 \\
\hline EDQQQGEDEHQDKIYPS & 42 & 58 \\
\hline DQQQGEDEHQDKIYPS & 43 & 58 \\
\hline LPVPQPEIMEVPKAKDT & 91 & 107 \\
\hline AKDTVYTKGRVMPVLK & 104 & 119 \\
\hline KDTVYTKGRVMPVLK & 105 & 119 \\
\hline GRVMPVLKSPTIPFFDPQIPK & 112 & 132 \\
\hline MPVLKSPTIPFFDPQIP & 115 & 131 \\
\hline VLPIPQQWPYPQ & 176 & 188 \\
\hline LLNPTHQIYPVTQPLAPVHNPISV & 203 & 226 \\
\hline NPTHQIYPVTQPLAPVHNPIS & 205 & 225 \\
\hline NPTHQIYPVTQPLAPVHNPISV & 205 & 226 \\
\hline YPVTQPLAPVHNPISV & 211 & 226 \\
\hline
\end{tabular}

"Start" and "stop" indicate the amino acid numbers for the beginning and end of the peptide within the protein sequence (counting the signal sequence).

At the P1 amino acid position, the amino acid most often present was lysine followed by arginine, alanine, and serine (Figures 6 and 7). All of these amino acids were present at more cleavage sites in hindmilk than foremilk by count. Compared to peptides with lysine, arginine, and alanine at P1, peptides with serine at P1 were much less abundant. Cleavage sites with a lysine and arginine at P1 correspond with the known site specificity for plasmin, KLK 6, KLK 11, and thrombin. Peptides with proline, 
TABLE 3 | Peptides derived from osteopontin identified in both foremilk and hindmilk samples from all four mothers.

\begin{tabular}{|c|c|c|}
\hline Sequence & Start & Stop \\
\hline IPVKQADSGSSEEKQLYNK & 17 & 35 \\
\hline IPVKQADSGSSEEKQLYNKYPDAVATWLNPDPSQ & 17 & 50 \\
\hline IPVKQADSGSSEEKQLYNKYPDAVATWLNPDPSQK & 17 & 51 \\
\hline IPVKQADSGSSEEKQLYNKYPDAVATWLNPDPSQKQN & 17 & 53 \\
\hline VKQADSGSSEEKQLYNKYPDAVATWLNPDPSQK & 19 & 51 \\
\hline SKSKKFRRPDIQYPDATDEDITSH & 169 & 192 \\
\hline SKSKKFRRPDIQYPDATDEDITSHMESEELNGAY & 169 & 202 \\
\hline SKSKKFRRPDIQYPDATDEDITSHMESEELNGAYK & 169 & 203 \\
\hline SKKFRRPDIQYPDATDEDITSHMESEELNGAYK & 171 & 203 \\
\hline KFRRPDIQYPDATDEDITSHMESEELNGAYK & 173 & 203 \\
\hline FRRPDIQYPDATDEDITSHMESEELNGAY & 174 & 202 \\
\hline FRRPDIQYPDATDEDITSHMESEELNGAYK & 174 & 203 \\
\hline RRPDIQYPDATDEDITSHMESEELNGAY & 175 & 202 \\
\hline RRPDIQYPDATDEDITSHMESEELNGAYK & 175 & 203 \\
\hline RPDIQYPDATDED & 176 & 188 \\
\hline RPDIQYPDATDEDITSH & 176 & 192 \\
\hline RPDIQYPDATDEDITSHMESEELNGAY & 176 & 202 \\
\hline RPDIQYPDATDEDITSHMESEELNGAYK & 176 & 203 \\
\hline PDIQYPDATDEDITSHMESEELNGAYK & 177 & 203 \\
\hline DIQYPDATDEDITSH & 178 & 192 \\
\hline DIQYPDATDEDITSHMESEELNGAYK & 178 & 203 \\
\hline IQYPDATDEDITSHMESEELNGAYK & 179 & 203 \\
\hline YPDATDEDITSH & 181 & 192 \\
\hline ESEELNGAYK & 194 & 203 \\
\hline AIPVAQDLNAPSDWDSRGKDSYETSQLDDQSAETHSHK & 204 & 241 \\
\hline RKANDESNEHSDVIDSQELSK & 248 & 268 \\
\hline HLKFRISHELDSASSEVN & 297 & 314 \\
\hline FRISHELDSASSEVN & 300 & 314 \\
\hline RISHELDSASSEVN & 301 & 314 \\
\hline
\end{tabular}

"Start" and "stop" indicate the amino acid numbers for the beginning and end of the peptide within the protein sequence (counting the signal sequence).

valine, glutamine, asparagine, isoleucine, phenylalanine, and tryptophan at the P1 position were also significantly higher in hindmilk compared with foremilk, by count. Of these, tyrosine, asparagine, and isoleucine at the $\mathrm{P} 1$ position of cleavage sites correspond with the site specificity of elastase. By abundance, only serine $(P=0.0258)$ and leucine $(P=0.0004)$ at the $\mathrm{P} 1$ position were significantly greater in hindmilk compared to foremilk.

At the $\mathrm{P} 1^{\prime}$ position of each cleavage site, the amino acids alanine $(P=0.0258)$, leucine $(P=0.0155)$, glutamic acid $(P=0.0473)$, proline $(P=0.0057)$, glutamine $(P=0.0115)$, tyrosine $(P=0-0249)$, aspartic acid $(P=0.0071)$, and methionine $(P=0.0253)$ were significantly higher in hindmilk than foremilk by count. Of these, only alanine at the $\mathrm{P} 1^{\prime}$ position corresponds with one of our listed protease cleavage preferences (thrombin).

Though examining the $\mathrm{P} 1$ and $\mathrm{P} 1^{\prime}$ amino acids can indicate matches with enzyme cleavage specificity, enzyme cleavage patterns are often more complex than their $\mathrm{P} 1$ and $\mathrm{P} 1$ ' preferences. Two tools predict which proteases are most likely responsible for peptide cleavages based on a more complex cleavage specificity pattern. Based on data from EnzymePredictor analysis, plasmin was involved in the most cleavages by count in both foremilk and hindmilk (Table 5). There were no significant differences in the odds ratios (i.e., the likelihood of protease activity) for any of the proteases between foremilk and hindmilk. However, the C-terminal $(P=0.0007)$ and total cleavage counts $(P=0.0162)$ assigned to plasmin and the $\mathrm{N}$-terminal
TABLE 4 | Peptides identified with a significantly higher abundance in hindmilk than foremilk.

\begin{tabular}{|c|c|c|c|}
\hline Sequence & Protein & Start & Stop \\
\hline LPIPQQWPYPQRA & $\beta$-Casein & 177 & 190 \\
\hline YPVTQPLAPVHNPISV & $\beta$-Casein & 211 & 226 \\
\hline LAQPAWLPVPQPEIMEVPKAKDT & $\beta$-Casein & 84 & 107 \\
\hline $\begin{array}{l}\text { STDRSPYEKVSAGNGGSSLS } \\
\text { YTNPAVAATSANL }\end{array}$ & Mucin-1 & 1,223 & 1,255 \\
\hline RLQNPSESSEPIPLESREEY & $\alpha_{\mathbf{S 1}}-$ Casein & 26 & 45 \\
\hline LAQPAWVLPVPQPEIMEVPKA & $\beta$-Casein & 84 & 104 \\
\hline DQQQGEDEHQDKIYPS & $\beta$-Casein & 43 & 58 \\
\hline RQRNILREKQTDEIKDTR & $\alpha_{\mathrm{S} 1}$-Casein & 51 & 68 \\
\hline LESREEYMNGMNR & $\alpha_{s 1}$-Casein & 39 & 51 \\
\hline $\begin{array}{l}\text { RSPYEKVSAGNGGSSLSYTN } \\
\text { PAVAATSANL }\end{array}$ & Mucin-1 & 1,226 & 1,255 \\
\hline IPLSPMGEDSAPR & $\begin{array}{l}\text { Butyrophilin subfamily } 1 \\
\text { member A1 }\end{array}$ & 495 & 507 \\
\hline $\begin{array}{l}\text { AQPAWLPVPQPEIME } \\
\text { VPKAKDTVYTK }\end{array}$ & $\beta$-Casein & 85 & 111 \\
\hline EIPLSPMGEDS & $\begin{array}{l}\text { Butyrophilin subfamily } 1 \\
\text { member A1 }\end{array}$ & 494 & 504 \\
\hline SPYEKVSAGNGGSSL & Mucin-1 & 1,227 & 1,241 \\
\hline $\begin{array}{l}\text { EEKAVADTRDQADGSRASV } \\
\text { DSGSSEEQGGSSR }\end{array}$ & $\begin{array}{l}\text { Polymeric immunoglobulin } \\
\text { receptor }\end{array}$ & 607 & 638 \\
\hline PMGEDSAPRDADTLH & $\begin{array}{l}\text { Butyrophilin subfamily } 1 \\
\text { member A1 }\end{array}$ & 499 & 513 \\
\hline SPYEKVSAGNGGSSLS & Mucin-1 & 1,227 & 1,242 \\
\hline PAWLPVPQPEIMEVPK & $\beta$-Casein & 87 & 103 \\
\hline NPTHQIYPVTQPLAPVHNP & $\beta$-Casein & 205 & 223 \\
\hline LSSSEESITEYK & $\beta$-Casein & 22 & 33 \\
\hline DSVDIFK & Bile salt-activated lipase & 45 & 51 \\
\hline LPIIQKLEPQIA & Perilipin-2 & 66 & 77 \\
\hline YTKGRVMPVLK & $\beta$-Casein & 109 & 119 \\
\hline TNPAVAATSANL & Mucin-1 & 1,244 & 1,255 \\
\hline PLSPMGEDSAPRD & $\begin{array}{l}\text { Butyrophilin subfamily } 1 \\
\text { member A1 }\end{array}$ & 496 & 508 \\
\hline $\begin{array}{l}\text { AIPVAQDLNAPSDWDS } \\
\text { RGKDSYETSQL }\end{array}$ & Osteopontin & 204 & 230 \\
\hline NGFKSHALQLNNRQIR & Complement C4-A & 1,337 & 1,352 \\
\hline DGREQEAEQMPEYRG & $\begin{array}{l}\text { Butyrophilin subfamily } 1 \\
\text { member A1 }\end{array}$ & 79 & 93 \\
\hline KEIPLSPMGEDSAPR & $\begin{array}{l}\text { Butyrophilin subfamily } 1 \\
\text { member A1 }\end{array}$ & 493 & 507 \\
\hline PVTQPLAPVHNPISV & $\beta$-Casein & 212 & 226 \\
\hline IESLSSSEESITEYKQKVEK & $\beta$-Casein & 19 & 38 \\
\hline LQNPSESSEPIPLESREEYMNGMN & $\alpha_{S 1}$-Casein & 27 & 50 \\
\hline QPLMQQVPQPIPQT & $\beta$-Casein & 147 & 160 \\
\hline PAVAATSANL & Mucin-1 & 1,246 & 1,255 \\
\hline AIPVAQDLNAPS & Osteopontin & 204 & 215 \\
\hline HQIYPVTQPLAPVHNPISV & $\beta$-Casein & 208 & 226 \\
\hline
\end{tabular}

"Start" and "stop" indicate the amino acid numbers for the beginning and end of the peptide within the protein sequence (counting the signal sequence).

$(P=0.0028)$ and total cleavage counts $(P=0.0085)$ assigned to elastase were higher in hindmilk compared with foremilk. Thrombin was only found to be responsible for one cleavage; however, the number of expected cleavages was low as well, resulting in a high odds ratio. KLK 6 and 11 are not available for search within Enzyme Predictor.

Proteasix also predicted that plasmin cleaved the largest number of peptides in the dataset. By this analysis, there were no differences for any of the predicted protease activities between foremilk and hindmilk; however, cleavages assigned to elastase tended to be higher in hindmilk compared with 

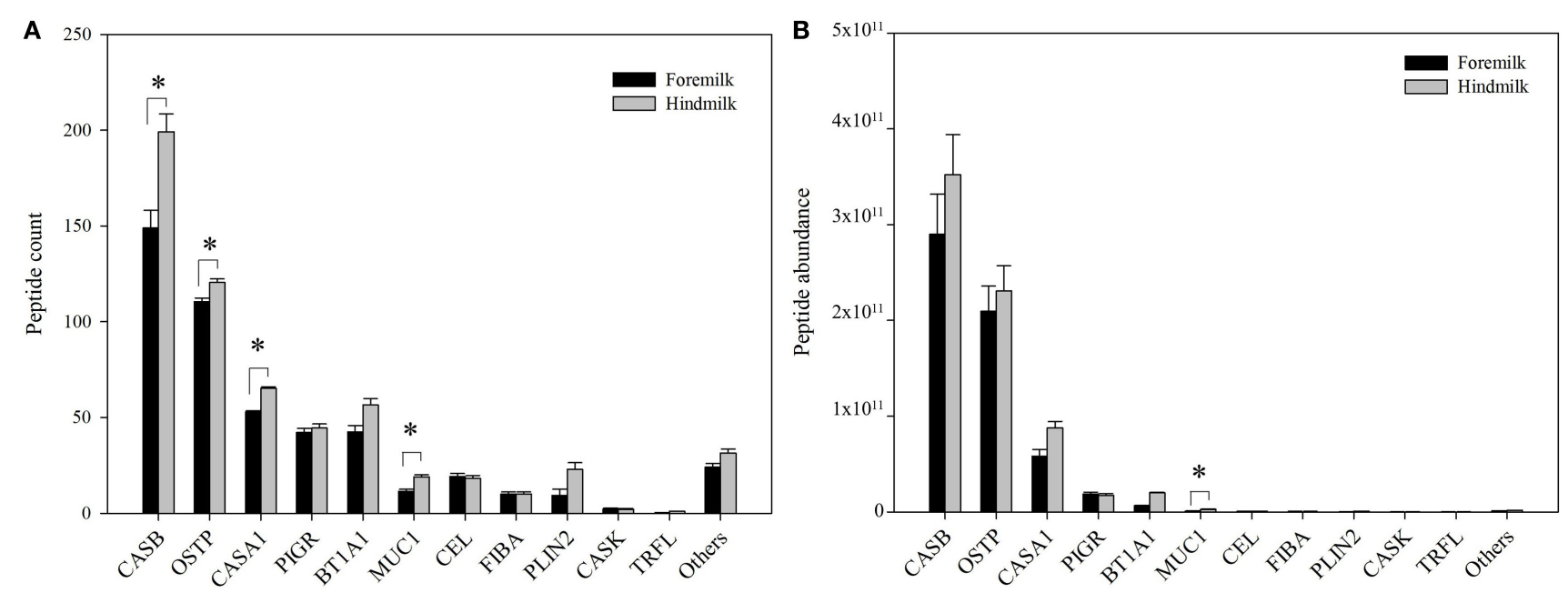

FIGURE 2 | Count $(\mathbf{A})$ and abundance $(\mathbf{B})$ of peptides derived from either foremilk or hindmilk. Results are shown as least square means \pm SE, $n=4$. Asterisks $\left(^{*}\right)$ indicate significant differences between foremilk and hindmilk $(P<0.05)$. CASB, $\beta$-casein; OSTP, osteopontin; CASA1, $\alpha_{\mathrm{s} 1}$-casein; BT1A1, butyrophilin subfamily 1 member A1; PIGR, polymeric immunoglobulin receptor; CEL, bile salt-activated lipase; PLIN2, perilipin-2; MUC1, mucin-1; FIBA, fibrinogen $\alpha$-chain; CASK, $\kappa$-casein; TRFL, lactoferrin.

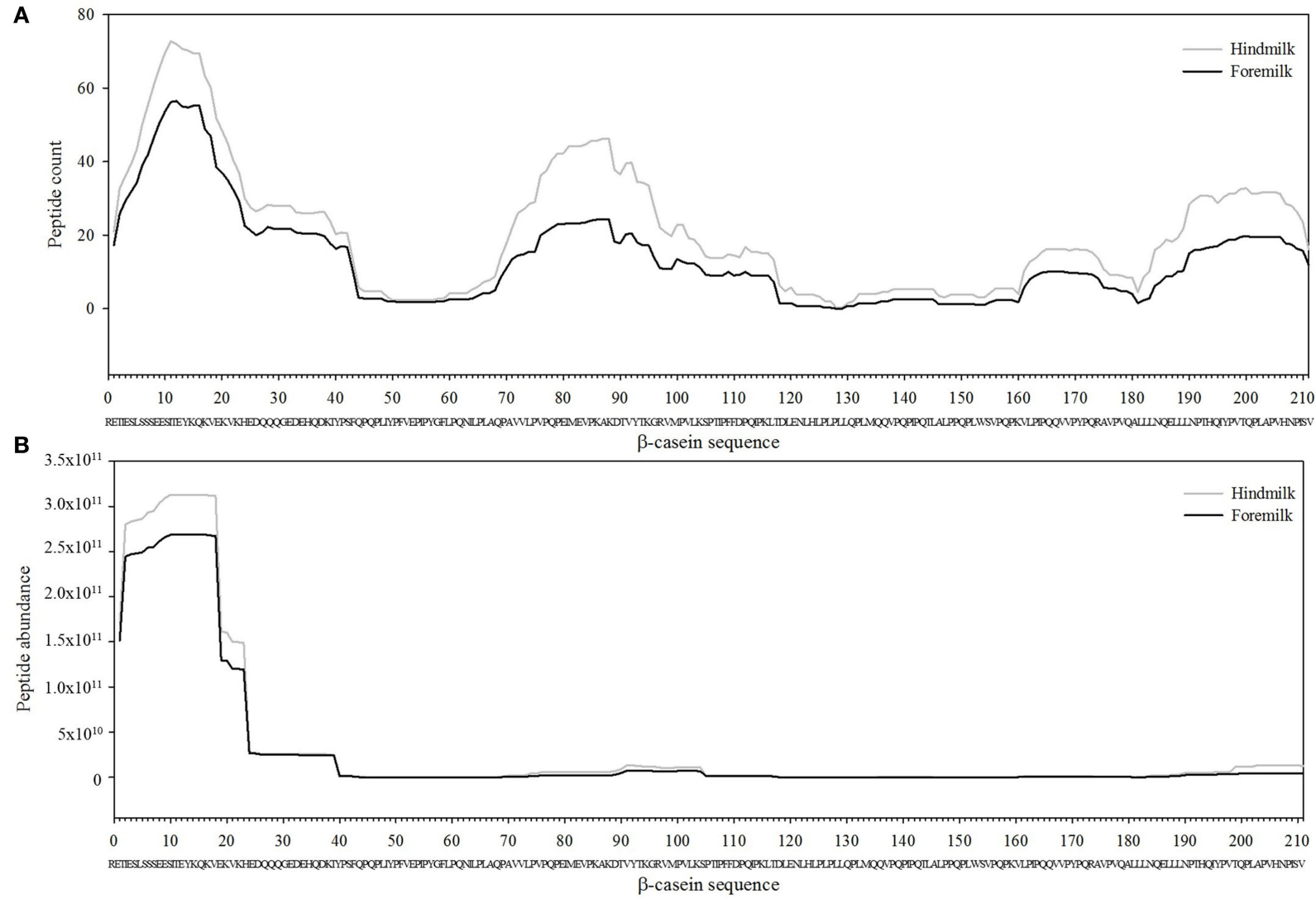

FIGURE 3 | Count (A) and abundance (B) of peptides identified in breast milk mapped on the sequence of $\beta$-casein.

foremilk $(P=0.0572)$ (Table 6). More cleavage sites were unassigned in hindmilk than foremilk $(P=0.0137)$, as only $15.5 \pm 0.4 \%$ of potential cleavages were assigned by Proteasix in hindmilk compared with $17.6 \pm 0.4 \%$ in foremilk. Several cleavage sites were assigned to two or more of plasmin, KLK 6 and thrombin as Proteasix was not able to distinguish among 
A

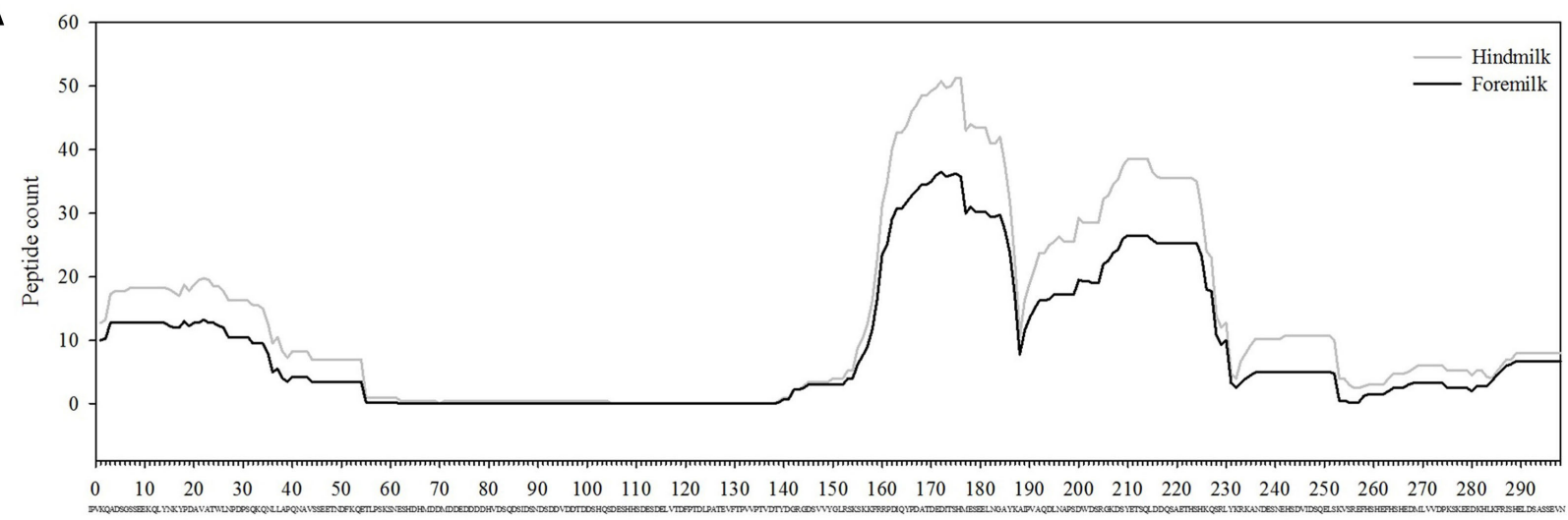

B

Osteopontin sequence

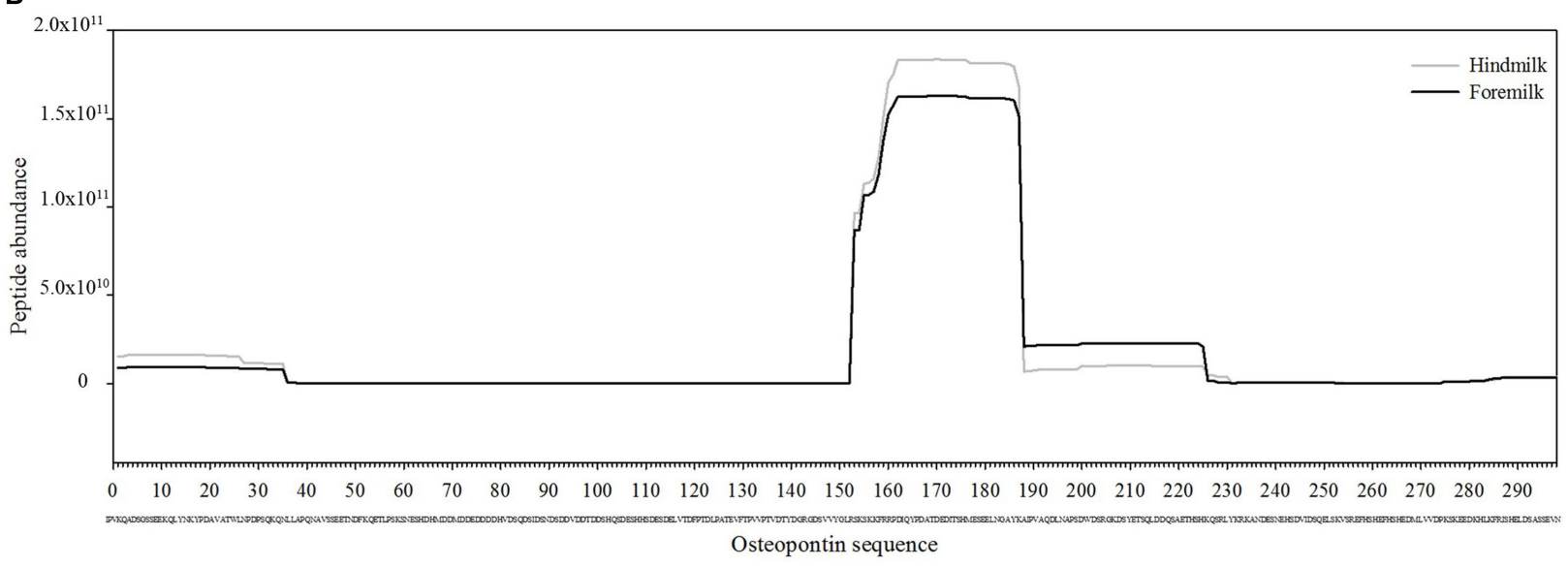

FIGURE 4 | Count (A) and abundance (B) of peptides identified in breast milk mapped on the sequence of osteopontin.

these enzymes for a number of the cleavage sites. On average, 14 cleavage sites overlapped between plasmin and thrombin, 3 overlapped between KLK 6 and plasmin, 1 overlapped between thrombin and KLK 6 and 1 cleavage site overlapped among all three enzymes.

A large portion of the identified peptides could not be assigned to a specific enzyme. However, several of these peptides matched other peptides with sequential removal of single amino acids. These could be potentially assigned to exopeptidase activity. N-terminal sequential removal of amino acids, potentially representing aminopeptidase activity, was significantly higher in hindmilk $(357.0 .5 \pm 9.4)$ than foremilk $(294.5 \pm 9.4)$ $(P=0.0190)$ by count, but it was not higher by abundance $\left(4.6 \times 10^{11} \pm 4.9 \times 10^{10}\right.$ vs. $\left.3.7 \times 10^{11} \pm 4.9 \times 10^{10}\right)$. C-terminal sequential removal of amino acids, potentially representing carboxypeptidase activity, was similarly higher by count in hindmilk ( $384.0 \pm 10.2$ peptides) than foremilk $(302.8 \pm 10.2)$ $(P=0.0109)$, but not abundance $\left(3.5 \times 10^{11} \pm 3.5 \times 10^{10}\right.$ vs. $\left.2.7 \times 10^{11} \pm 3.5 \times 10^{10}\right)$.

\section{Bioactivity}

Searching the MBPDB for identified peptide homology with known bioactive peptides revealed two peptides with $100 \%$ alignment to a known bioactive peptide (Table 7). These two peptides derived from $\beta$-casein f105-117 (SPTIPFFDPQIPK) and f185-211 (QELLLNPTHQIYPVTQPLAPVHNPISV), which were identified in 7 and 5 of the eight milk samples, respectively. $\beta$-Casein f105-117 can increase cell proliferation (29), and $\beta$-casein f185-211 is antimicrobial (30). The abundances of these two peptides were not different between the foremilk and hindmilk. With an 80\% homology threshold, an additional five peptides matched to $\beta$-casein f105-117 and an additional 21 peptides matched to $\beta$-casein f185-211. The total abundance of the peptides with $>80 \%$ homology to the antimicrobial $\beta$-casein f185-211 was higher in hindmilk than foremilk $(P=0.0429)$, but not the total count $(P=0.1602)$. Neither the total abundance nor the total count of the peptides with $>80 \%$ homology to $\beta$-casein f105-117 differed between foremilk and hindmilk. This search also identified six peptides with $>80 \%$ homology to known ACE-inhibitory peptides and one additional peptide with $>80 \%$ homology to a known antimicrobial peptide.

Bioactivity prediction software (CAMPR3) predicted a higher number of antimicrobial peptides in hindmilk $(81 \pm 4)$ compared to foremilk $(62 \pm 4)(P=0.0381)$. The abundance of these peptides tended to be higher in hindmilk than foremilk 

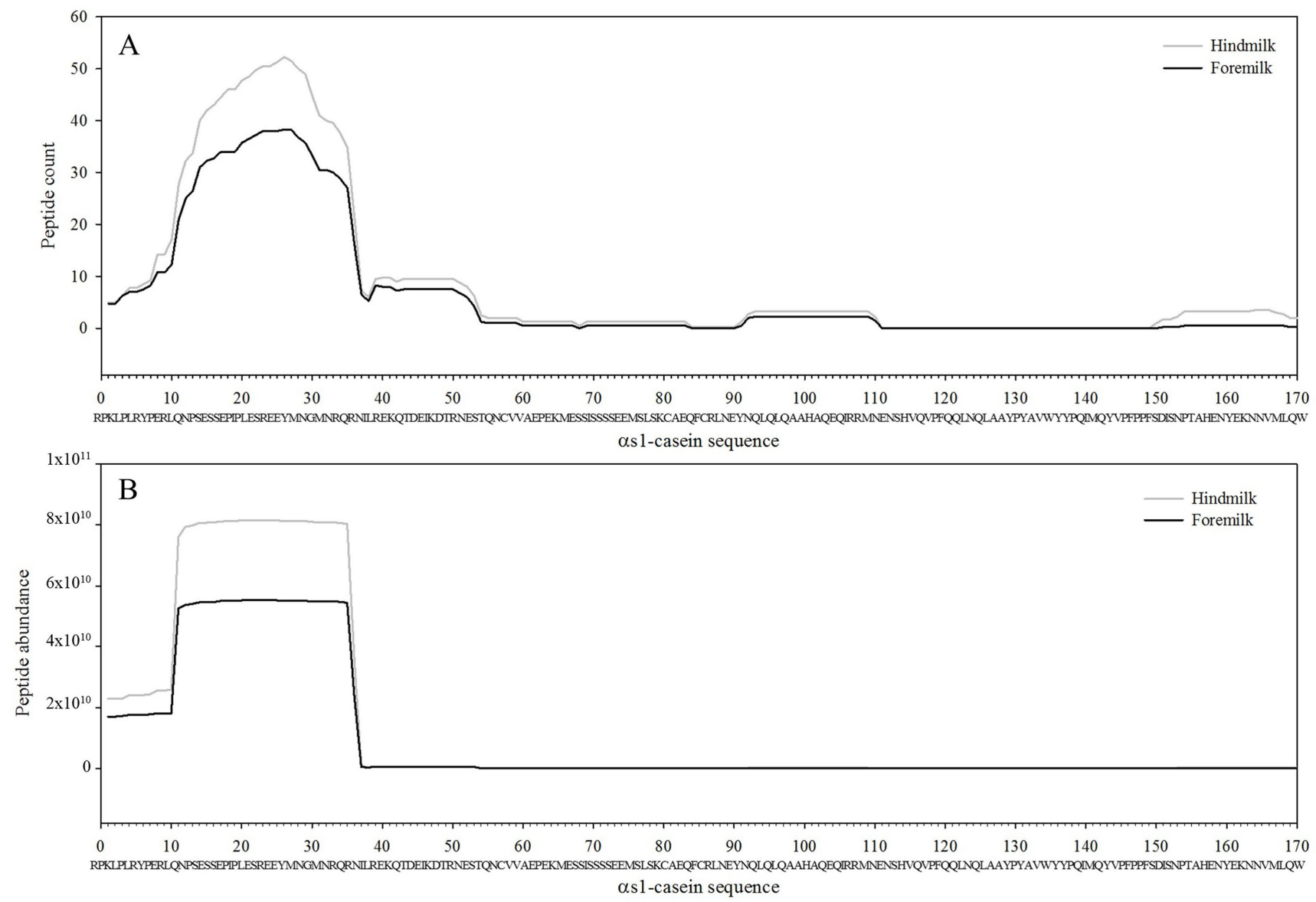

FIGURE 5 | Count (A) and abundance (B) of peptides identified in breast milk mapped on the sequence of $\alpha_{s_{1} 1}$-casein.

( $P=0.0927$ ) (Table 7$)$. However, the percentage of predicted antimicrobial peptides among the total identified peptides did not differ between foremilk $(13.2 \pm 0.6 \%$ by count, $1.9 \pm 1.4 \%$ by abundance) and hindmilk ( $13.7 \pm 0.6 \%$ by count, $4.3 \pm 1.4 \%$ by abundance).

The count of general bioactive peptides as predicted by Peptide Ranker was also higher in hindmilk $(65 \pm 2)$ compared to foremilk $(56 \pm 2)(P=0.0306)$. The abundance of these peptides tended to be higher in hindmilk than foremilk $(P=0.0773)$ (Table 7). However, the percentage of predicted bioactive peptides compared to the total did not differ between foremilk and hindmilk by count $(11.7 \pm 0.3$ vs. $11.0 \pm 0.3 \%$, respectively). The percentage abundance of predicted general bioactive peptides compared to the total tended to be higher in hindmilk $(13.4 \pm 0.4 \%)$ than foremilk $(11.8 \pm 0.4 \%)(P=0.0555)$.

\section{DISCUSSION}

The findings from this study show that hindmilk contained a higher total count of peptides than foremilk, with no difference in peptide abundance. The difference in count derived from higher counts of peptides from $\beta$-casein, osteopontin, $\alpha_{s 1}$-casein, and mucin-1. The most abundant proteins in human milk are $\beta$-casein, $\alpha_{s 1}$-casein, $\alpha$-lactalbumin, lactoferrin, immunoglobulin A, lysozyme, and serum albumin (31). Though peptides derived from casein proteins were identified, no peptides were identified from $\alpha$-lactalbumin, immunoglobulin A, lysozyme, or serum albumin and only a single peptide was identified from lactoferrin. These proteins thus may not be hydrolyzed inside the mammary gland, enabling their continued function in the neonatal gut. Overall, the peptides identified in foremilk and hindmilk were highly similar to each other. This protein-specific peptide release pattern is similar to results from past human milk peptidomic studies $(7,16,17)$.

As milk was pumped directly into a mixture of antiproteases on ice, followed by immediate freezing to ensure that no proteolytic activity would occur in these milk samples post expression, peptides identified here represent the hydrolysis of proteins by proteases within the mammary gland. In the time between expressions, milk components gradually pool within the mammary gland. This time period provides the incubation time necessary for the initiation of protein hydrolysis. As the milk is held at body temperature and most of the enzymes are most active at body temperature, this environment provides ideal incubation conditions for these enzymes. The findings of the present study confirm findings of previous studies that 


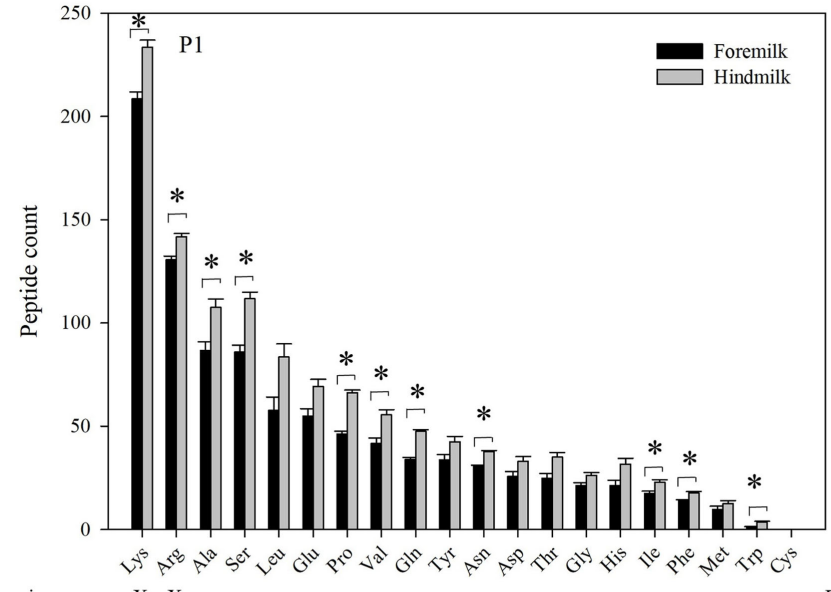

Plasmin

Elastase

Thrombi

Kallikrein 6

$\mathrm{X} \quad \mathrm{X}$

$\begin{array}{ll}X & X \\ X & X\end{array}$

$\begin{array}{ll}X & X\end{array}$
X X

$\mathrm{X}$
$\mathrm{X}$

(a)

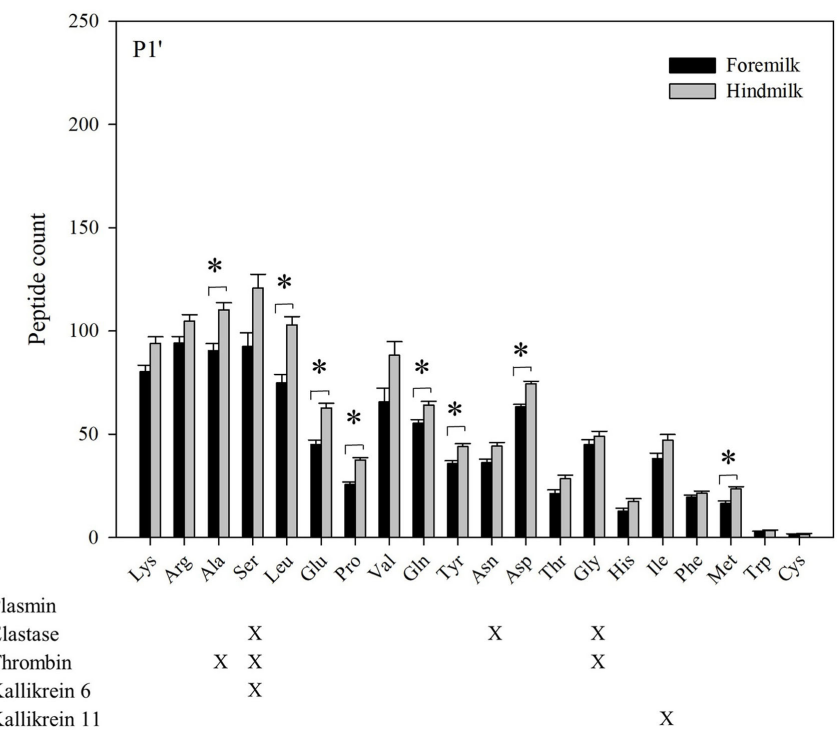

FIGURE 6 | Count of peptides distributed according to their P1 and P1' cleavage site of foremilk and hindmilk. Results are shown as least square mean \pm SE, $n=4$. Asterisks $\left(^{*}\right)$ indicate significant difference between foremilk and hindmilk $(P<0.05)$.

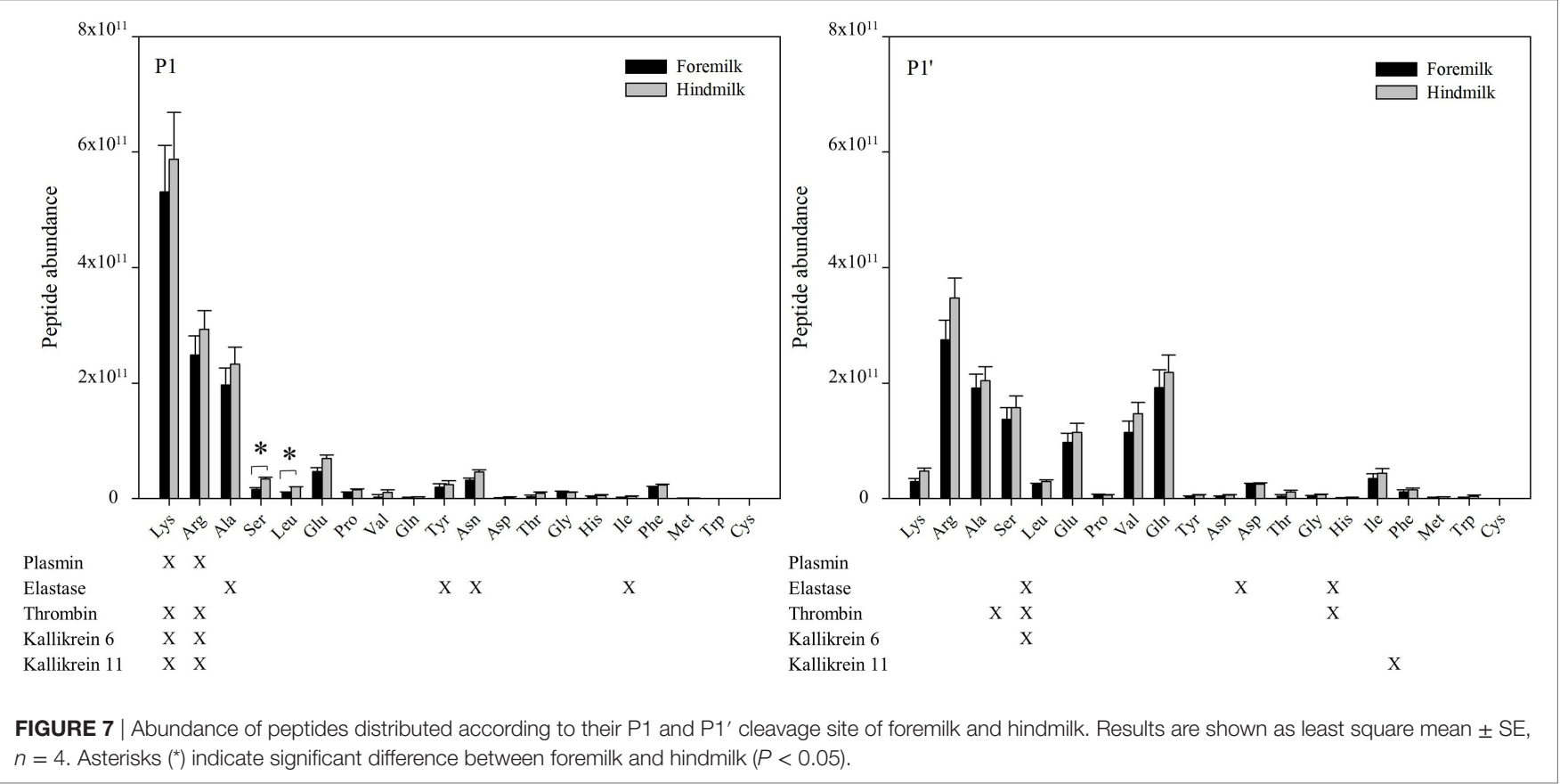

TABLE 5 | Proteases involved in digestion of human milk proteins as predicted by enzyme predictor.

\begin{tabular}{|c|c|c|c|c|c|c|c|c|}
\hline Enzyme & & $\begin{array}{c}\mathrm{N} \text {-terminal } \\
\text { cleavage count }\end{array}$ & $\begin{array}{c}\text { C-terminal } \\
\text { cleavage count }\end{array}$ & Total cleavage & $\begin{array}{l}\text { Unique } \\
\text { cleavage }\end{array}$ & $\begin{array}{l}\text { No. of expected cleavages } \\
\text { within the peptide }\end{array}$ & $\begin{array}{c}\text { Number of } \\
\text { proteins cleaved }\end{array}$ & Odds ratio \\
\hline \multirow[t]{2}{*}{ Plasmin } & Foremilk & $144.0 \pm 4.6$ & $194.0 \pm 0.9$ & $338.0 \pm 5.1$ & $0.0 \pm 0.0$ & $564.00 \pm 13.63$ & $19.50 \pm 0.34$ & $3.6 \pm 0.1$ \\
\hline & Hindmilk & $161.0 \pm 4.6$ & $212.5 \pm 0.9^{*}$ & $373.5 \pm 5.1^{*}$ & $0.0 \pm 0.0$ & $682.50 \pm 13.63^{*}$ & $19.75 \pm 0.34$ & $3.3 \pm 0.1$ \\
\hline \multirow[t]{2}{*}{ Elastase } & Foremilk & $54.3 \pm 1.6$ & $52.5 \pm 3.3$ & $106.8 \pm 2.7$ & $0.0 \pm 0.0$ & $633.00 \pm 18.63$ & $11.50 \pm 0.44$ & $0.9 \pm 0.0$ \\
\hline & Hindmilk & $74.8 \pm 1.6^{\star}$ & $55.3 \pm 3.3$ & $130.0 \pm 2.7^{\star}$ & $0.0 \pm 0.0$ & $801.00 \pm 18.63^{*}$ & $14.25 \pm 0.4^{*}$ & $0.9 \pm 0.0$ \\
\hline \multirow[t]{2}{*}{ Thrombin } & Foremilk & $0.2 \pm 0.2$ & $0.0 \pm 0.0$ & $0.3 \pm 0.2$ & $0.3 \pm 0.2$ & $0.3 \pm 0.2$ & $0.3 \pm 0.2$ & $1.3 \pm 2.9$ \\
\hline & Hindmilk & $0.5 \pm 0.2$ & $0.0 \pm 0.0$ & $0.5 \pm 0.2$ & $0.5 \pm 0.2$ & $0.5 \pm 0.2$ & $0.5 \pm 0.2$ & $8.1 \pm 2.9$ \\
\hline
\end{tabular}

Results are shown as least square mean $\pm S E, n=4$. Asterisks $\left(^{*}\right)$ indicate significant difference between foremilk and hindmilk (P < 0.05). 
TABLE 6 | Proteases involved in digestion of breast milk proteins as predicted by Proteasix.

\begin{tabular}{|c|c|c|c|c|c|c|}
\hline & Plasmin & Elastase & Thrombin & Kallikrein 6 & Kallikrein 11 & Unassigned \\
\hline Foremilk & $97.8 \pm 1.2$ & $25.0 \pm 2.8$ & $24.0 \pm 1.4$ & $7.5 \pm 0.6$ & $0.0 \pm 0.0$ & $718.3 \pm 26.5$ \\
\hline Hindmilk & $100.3 \pm 1.2$ & $36.8 \pm 2.8$ & $24.08 \pm 1.4$ & $9.0 \pm 0.6$ & $0.0 \pm 0.0$ & $914.0 \pm 26.5^{\star}$ \\
\hline
\end{tabular}

Results are shown as least square mean \pm SE of the number of cleavages, $n=4$. Asterisks $\left(^{*}\right)$ indicate significant difference between foremilk and hindmilk (P <0.05).

TABLE 7 | Bioactive peptides in human foremilk and hindmilk samples.

\begin{tabular}{|c|c|c|c|c|}
\hline Query peptide & Protein & Bioactive peptide & Function & Alignment \\
\hline QELLLNPTHQIYPVTQPLAPVHNPISV & $\beta$-Casein & QELLLNPTHQIYPVTQPLAPVHNPISV & Antimicrobial & 100.0 \\
\hline NQELLLNPTHQIYPVTQPLAPVHNPISV & $\beta$-Casein & QELLLNPTHQIYPVTQPLAPVHNPISV & Antimicrobial & 96.4 \\
\hline ELLLNPTHQIYPVTQPLAPVHNPISV & $\beta$-Casein & QELLLNPTHQIYPVTQPLAPVHNPISV & Antimicrobial & 96.3 \\
\hline NQELLLNPTHQIYPVTQPLAPVHNPIS & $\beta$-Casein & QELLLNPTHQIYPVTQPLAPVHNPISV & Antimicrobial & 96.3 \\
\hline QELLLNPTHQIYPVTQPLAPVHNPIS & $\beta$-Casein & QELLLNPTHQIYPVTQPLAPVHNPISV & Antimicrobial & 96.3 \\
\hline LNQELLLNPTHQIYPVTQPLAPVHNPISV & $\beta$-Casein & QELLLNPTHQIYPVTQPLAPVHNPISV & Antimicrobial & 93.1 \\
\hline LNQELLLNPTHQIYPVTQPLAPVHNPIS & $\beta$-Casein & QELLLNPTHQIYPVTQPLAPVHNPISV & Antimicrobial & 92.9 \\
\hline ELLLNPTHQIYPVTQPLAPVHNPIS & $\beta$-Casein & QELLLNPTHQIYPVTQPLAPVHNPISV & Antimicrobial & 92.6 \\
\hline NQELLLNPTHQIYPVTQPLAPVHNPI & $\beta$-Casein & QELLLNPTHQIYPVTQPLAPVHNPISV & Antimicrobial & 92.6 \\
\hline LLNQELLLNPTHQIYPVTQPLAPVHNPISV & $\beta$-Casein & QELLLNPTHQIYPVTQPLAPVHNPISV & Antimicrobial & 90.0 \\
\hline LLNQELLLNPTHQIYPVTQPLAPVHNPIS & $\beta$-Casein & QELLLNPTHQIYPVTQPLAPVHNPISV & Antimicrobial & 89.7 \\
\hline LLNQELLLNPTHQIYPVTQPLAPVHNPI & $\beta$-Casein & QELLLNPTHQIYPVTQPLAPVHNPISV & Antimicrobial & 89.3 \\
\hline LLLNPTHQIYPVTQPLAPVHNPIS & $\beta$-Casein & QELLLNPTHQIYPVTQPLAPVHNPISV & Antimicrobial & 88.9 \\
\hline LLNPTHQIYPVTQPLAPVHNPISV & $\beta$-Casein & QELLLNPTHQIYPVTQPLAPVHNPISV & Antimicrobial & 88.9 \\
\hline NQELLLNPTHQIYPVTQPLAPVHNP & $\beta$-Casein & QELLLNPTHQIYPVTQPLAPVHNPISV & Antimicrobial & 88.9 \\
\hline LLNPTHQIYPVTQPLAPVHNPIS & $\beta$-Casein & QELLLNPTHQIYPVTQPLAPVHNPISV & Antimicrobial & 85.2 \\
\hline LNPTHQIYPVTQPLAPVHNPISV & $\beta$-Casein & QELLLNPTHQIYPVTQPLAPVHNPISV & Antimicrobial & 85.2 \\
\hline ALLLNQELLLNPTHQIYPVTQPLAPVHNPISV & $\beta$-Casein & QELLLNPTHQIYPVTQPLAPVHNPISV & Antimicrobial & 84.4 \\
\hline LLNQELLLNPTHQIYPVTQPLAPVH & $\beta$-Casein & QELLLNPTHQIYPVTQPLAPVHNPISV & Antimicrobial & 81.5 \\
\hline LNPTHQIYPVTQPLAPVHNPIS & $\beta$-Casein & QELLLNPTHQIYPVTQPLAPVHNPISV & Antimicrobial & 81.5 \\
\hline NPTHQIYPVTQPLAPVHNPISV & $\beta$-Casein & QELLLNPTHQIYPVTQPLAPVHNPISV & Antimicrobial & 81.5 \\
\hline NQELLLNPTHQIYPVTQPLAPVH & $\beta$-Casein & QELLLNPTHQIYPVTQPLAPVHNPISV & Antimicrobial & 81.5 \\
\hline SPTIPFFDPQIPK & $\beta$-Casein & SPTIPFFDPQIPK & Stimulates cell proliferation & 100.0 \\
\hline KSPTIPFFDPQIPK & $\beta$-Casein & SPTIPFFDPQIPK & Stimulates cell proliferation & 92.9 \\
\hline SPTIPFFDPQIPKL & $\beta$-Casein & SPTIPFFDPQIPK & Stimulates cell proliferation & 92.9 \\
\hline SPTIPFFDPQIP & $\beta$-Casein & SPTIPFFDPQIPK & Stimulates cell proliferation & 92.3 \\
\hline LKSPTIPFFDPQIPK & $\beta$-Casein & SPTIPFFDPQIPK & Stimulates cell proliferation & 86.7 \\
\hline SPTIPFFDPQIPKLTD & $\beta$-Casein & SPTIPFFDPQIPK & Stimulates cell proliferation & 81.3 \\
\hline DTVYTKGRVMP & $\beta$-Casein & TVYTKGRVMP & ACE-inhibitory & 90.9 \\
\hline KDTVYTKGRVMP & $\beta$-Casein & TVYTKGRVMP & ACE-inhibitory & 83.3 \\
\hline TVYTKGRVMPVL & $\beta$-Casein & TVYTKGRVMP & ACE-inhibitory & 83.3 \\
\hline PFFDPQIPK & $\beta$-Casein & PFFDPQIP & ACE-inhibitory & 88.9 \\
\hline FFDPQIPK & $\beta$-Casein & PFFDPQIP & ACE-inhibitory & 87.5 \\
\hline LRQAQEKFGKDKSPKFQL & Lactoferrin & WNLLRQAQEKFGKDKSPK & Antimicrobial & 83.3 \\
\hline IYPSFQPQPLI & $\beta$-Casein & YPSFQPQPLIYP & ACE-inhibitory & 83.3 \\
\hline
\end{tabular}

Peptide abundance is shown as least square mean $\pm S E, n=4$. Asterisks $\left(^{*}\right)$ indicate significant difference between foremilk and hindmilk (P < 0.05$)$. Indented peptide sequences are related to a peptide present with $100 \%$ homology to a known bioactive peptide.

peptides are present in mother's milk due to intra-mammary proteolysis $(15,16)$.

As expression of milk takes $20-45 \mathrm{~min}$, the additional exposure in the mammary gland in contact with proteases prior to expression of hindmilk compared with the foremilk could have allowed for additional proteolytic action-observed as higher counts of peptides in hindmilk. However, as the total peptide abundance did not differ, the effect of additional time in the mammary gland on peptide release is limited.

The higher counts of peptides in hindmilk compared with foremilk mostly came from peptides with a lysine, arginine, alanine, and serine at the P1 position. These amino acids also were overall those most often identified at the $\mathrm{P} 1$ position for each cleavage site. The amino acids arginine and lysine at P1 match the cleavage specificities for plasmin, KLK 6, KLK 11, and thrombin. These proteases have partially overlapping cleavage specificity, making it impossible to distinguish between them on the basis of P1 alone. However, EnzymePredictor and Proteasix, which both use more complex analyses of cleavage specificity, predict that plasmin was the most active protease in milk. Proteasix also found cleavages that matched to elastase, thrombin and KLK 6, suggesting that they are also involved in proteolysis within the mammary gland. However, no cleavage sites were assigned to KLK 11 within Proteasix. None of the predicted protease activities were significantly different between foremilk and hindmilk within Proteasix and EnzymePredictor.

Unassigned cleavage sites were higher in hindmilk than foremilk as shown by Proteasix, which could indicate that other 
proteases not examined in these prediction algorithms are active and responsible for the overall differences in peptide profile between foremilk and hindmilk. Cytosol aminopeptidase and carboxypeptidase B2 are exopeptidases known to be active in milk (12), and a previous study has confirmed there to be free amino acids in human milk (32), which may derive from the activity of these exopeptidases. These proteases could account for the high number of unassigned cleavages, as these enzymes are not available as options in EnzymePredictor and Proteasix. Indeed, in hindmilk a significantly higher number of identified peptides corresponded to sets of peptides with sequential removal of amino acids from the $\mathrm{N}$ - and C-termini compared with foremilk.

Hindmilk showed a higher abundance of peptides with $>80 \%$ homology to the known antimicrobial peptide $\beta$-casein f185-211 (QELLLNPTHQIYPVTQPLAPVHNPISV) than foremilk. This peptide was originally identified after in vitro digestion of human milk with the protease Lactobacillus helveticus PR4 (30). However, we have shown that this peptide is produced naturally in the mammary gland in the absence of external protease activity and thus immediately available in active form to the infant or for action within the mammary gland itself. In an agar well diffusion assay (33), $\beta$-casein f185-211 demonstrated inhibitory activity against the potentially pathogenic species Escherichia coli, Enterococcus faecium, Bacillus megaterium, Listeria innocua, Salmonella spp., Yersinia enterocolitica, and Staphylococcus aureus. Several of these bacteria are known to inhabit the gut and may lead to infections in the infant, especially for those in neonatal care settings $(34,35)$.

In addition, hindmilk showed a higher number of peptides predicted to be potentially bioactive and also tended to be higher in abundance. However, on a percentage basis compared with the total number of peptides identified in each sample, hindmilk and foremilk did not differ in the relative amounts of predicted bioactive peptides. A potential limitation of our study in comparing bioactive peptide abundance is the small sample size $(n=4)$. However, as most peptides were found to be the same across fore- and hindmilk, the findings are likely robust.

The nutrient content of breast milk is considered to be insufficient to meet the needs of early pre-term infants and is typically fortified with additional nutrients, including protein $(36,37)$. Despite this fortification, pre-term infants with very low birth weight commonly have postnatal growth failure, which is associated with numerous long-term health issues. To provide the most optimal nutrition, some neonatal intensive care units feed low birth weight pre-term infants mother's hindmilk, as it is more energy dense, and preserve the foremilk by freezing for later use

\section{REFERENCES}

1. Ip S, Chung M, Raman G, Chew P, Magula N, Trikalinos T, et al. Breastfeeding and maternal and infant health outcomes in developed countries. Evid Rep Technol Assess (Full Rep) (2007) 153(153):1-186.

2. Mohanty DP, Mohapatra S, Misra S, Sahu PS. Milk derived bioactive peptides and their impact on human health - a review. Saudi J Biol Sci (2016) 23(5):577-83. doi:10.1016/j.sjbs.2015.06.005

3. Wada Y, Lönnerdal B. Bioactive peptides derived from human milk proteins mechanisms of action. J Nutr Biochem (2014) 25(5):503-14. doi:10.1016/j. jnutbio.2013.10.012

4. Clare DA, Swaisgood HE. Bioactive milk peptides: a prospectus. J Dairy Sci (2000) 83(6):1187-95. doi:10.3168/jds.S0022-0302(00)74983-6
$(21,38,39)$. Findings in the present study for milk of term mothers indicate that this practice may provide increased numbers of bioactive peptides to pre-term infants during hindmilk feeding should pre-term mothers' fore- and hindmilks differ similarly. As bioactive peptides may help protect and guide the development of the neonate, this contribution could lead to improved outcomes. Therefore, the potential to alter infant nutrition due to differences in peptides between foremilk and hindmilk is possible; however, as there are few differences in overall peptide abundance, the overall effect regarding peptides is likely limited.

\section{CONCLUSION}

The findings demonstrate that hindmilk contains a higher number of peptides than foremilk, including peptides with antimicrobial activity. However, peptide abundance both overall and from individual proteins was similar in foremilk and hindmilk.

\section{ETHICS STATEMENT}

This study was carried out in accordance with and approval by the Institutional Review Board at Oregon State University. Informed consent was obtained from all mothers.

\section{AUTHOR CONTRIBUTIONS}

SN and DD planned the study. SN collected the samples. SN and $\mathrm{RB}$ conducted the experiments and data analysis. SN, RB, and DD prepared the manuscript. All authors read and approved the final manuscript.

\section{ACKNOWLEDGMENTS}

The authors thank Melinda Spooner for assisting in collecting the human milk samples. The authors thank the Oregon State University Mass Spectrometry Center for assistance with the analysis. All authors read and approved the final manuscript.

\section{FUNDING}

This work was funded in part by the K99/R00 Pathway to Independence Career Award, Eunice Kennedy Shriver Institute of Child Health \& Development of the National Institutes of Health (R00HD079561) (DD).

5. Nielsen SD, Beverly RL, Qu Y, Dallas DC. Milk bioactive peptide database: a comprehensive database of milk protein-derived bioactive peptides and novel visualization. Food Chem (2017) 232:673-82. doi:10.1016/j.foodchem.2 017.04 .056

6. Hernandez-Ledesma B, Quiros A, Amigo L, Recio I. Identification of bioactive peptides after digestion of human milk and infant formula with pepsin and pancreatin. Int Dairy J (2007) 17(1):42-9. doi:10.1016/j.idairyj.2005.12.012

7. Wada Y, Loennerdal B. Bioactive peptides released from in vitro digestion of human milk with or without pasteurization. Pediatr Res (2015) 77(4): 546-53. doi:10.1038/pr.2015.10

8. Malinowski J, Klempt M, Clawin-Rädecker I, Lorenzen PC, Meisel H. Identification of a NFKB inhibitory peptide from tryptic $\beta$-casein hydrolysate. Food Chem (2014) 165:129-33. doi:10.1016/j.foodchem.2014.05.075 
9. Håversen L, Kondori N, Baltzer L, Hanson LA, Dolphin GT, Dunér K, et al. Structure-microbicidal activity relationship of synthetic fragments derived from the antibacterial alpha-helix of human lactoferrin. Antimicrob Agents Chemother (2010) 54(1):418-25. doi:10.1128/AAC.00908-09

10. Kohmura M, Nio N, Kubo K, Minoshima Y, Munekata E, Ariyoshi Y. Inhibition of angiotensin-converting enzyme by synthetic peptides of human $\beta$-casein. Agric Biol Chem (1989) 53(8):2107-14. doi:10.1271/bbb1961. 53.2107

11. Dallas DC, Murray NM, Gan J. Proteolytic systems in milk: perspectives on the evolutionary function within the mammary gland and the infant. J Mammary Gland Biol Neoplasia (2015) 20(3-4):133-47. doi:10.1007/ s10911-015-9334-3

12. Demers-Mathieu V, Nielsen SD, Underwood MA, Borghese R, Dallas DC. Analysis of milk from mothers who delivered prematurely reveals few changes in proteases and protease inhibitors across gestational age at birth and infant postnatal age. J Nutr (2017) 146(6):1152-9. doi:10.3945/jn.116. 244798

13. Dallas DC, German JB. Enzymes in human milk. Nestle Nutr Inst Workshop Ser (2017) 88:129-36. doi:10.1159/000455250

14. Dallas DC, Smink CJ, Robinson RC, Tian T, Guerrero A, Parker EA, et al. Endogenous human milk peptide release is greater after preterm birth than term birth. J Nutr (2015) 145(3):425-33. doi:10.3945/jn.114.203646

15. Guerrero A, Dallas DC, Contreras S, Chee S, Parker EA, Sun X, et al. Mechanistic peptidomics: factors that dictate specificity in the formation of endogenous peptides in human milk. Mol Cell Proteomics (2014) 13(12): 3343-51. doi:10.1074/mcp.M113.036194

16. Dallas DC, Guerrero A, Khaldi N, Castillo PA, Martin WF, Smilowitz JT, et al. Extensive in vivo human milk peptidomics reveals specific proteolysis yielding protective antimicrobial peptides. JProteome Res (2013) 12(5): 2295-304. doi:10.1021/pr400212z

17. Ferranti P, Traisci MV, Picariello G, Nasi A, Boschi V, Siervo M, et al. Casein proteolysis in human milk: tracing the pattern of casein breakdown and the formation of potential bioactive peptides. J Dairy Res (2004) 71(1): 74-87. doi:10.1017/S0022029903006599

18. Ferreira AM, Bislev SL, Bendixen E, Almeida AM. The mammary gland in domestic ruminants: a systems biology perspective. J Proteomics (2013) 94:110-23. doi:10.1016/j.jprot.2013.09.012

19. Valentine CJ, Hurst NM, Schanler RJ. Hindmilk improves weight gain in low-birth-weight infants fed human milk. J Pediatr Gastroenterol Nutr (1994) 18(4):474-7. doi:10.1097/00005176-199405000-00013

20. Bishara R, Dunn MS, Merko SE, Darling P. Volume of foremilk, hindmilk, and total milk produced by mothers of very preterm infants born at less than 28 weeks of gestation. J Hum Lact (2009) 25(3):272-9. doi:10.1177/ 0890334409334606

21. Bishara R, Dunn MS, Merko SE, Darling P. Nutrient composition of hindmilk produced by mothers of very low birth weight infants born at less than 28 weeks' gestation. J Hum Lact (2008) 24(2):159-67. doi:10.1177/ 0890334408316085

22. Ogechi A-A, William O, Fidelia B-T. Hindmilk and weight gain in preterm very low-birthweight infants. Pediatr Int (2007) 49(2):156-60. doi:10.1111/j.1442-200X.2007.02336.x

23. Saarela T, Kokkonen J, Koivisto M. Macronutrient and energy contents of human milk fractions during the first six months of lactation. Acta Paediatr (2005) 94(9):1176-81. doi:10.1080/08035250510036499

24. Smith PK, Krohn RI, Hermanson GT, Mallia AK, Gartner FH, Provenzano MD, et al. Measurement of protein using bicinchoninic acid. Anal Biochem (1985) 150(1):76-85. doi:10.1016/0003-2697(85)90442-7

25. Waghu FH, Barai RS, Gurung P, Idicula-Thomas S. CAMPR3: a database on sequences, structures and signatures of antimicrobial peptides. Nucleic Acids Res (2016) 44(D1):D1094-7. doi:10.1093/nar/gkv1051

26. Mooney C, Haslam NJ, Pollastri G, Shields DC. Towards the improved discovery and design of functional peptides: common features of diverse classes permit generalized prediction of bioactivity. PLoS One (2012) 7(10):e45012. doi:10.1371/journal.pone.0045012

27. Klein J, Eales J, Zürbig P, Vlahou A, Mischak H, Stevens R. Proteasix: a tool for automated and large-scale prediction of proteases involved in naturally occurring peptide generation. Proteomics (2013) 13(7):1077-82. doi:10.1002/pmic.201200493

28. Vijayakumar V, Guerrero AN, Davey N, Lebrilla CB, Shields DC, Khaldi N. EnzymePredictor: a tool for predicting and visualizing enzymatic cleavages of digested proteins. J Proteome Res (2012) 11(12):6056-65. doi:10.1021/ pr300721f

29. Azuma N, Nagaune S-I, Ishino Y, Mori H, Kaminogawa S, Yamauchi K. DNA-synthesis stimulating peptides from human $\beta$-casein. Agric Biol Chem (1989) 53(10):2631-4. doi:10.1080/00021369.1989.10869716

30. Minervini F, Algaron F, Rizzello CG, Fox PF, Monnet V, Gobbetti M. Angiotensin I-converting-enzyme-inhibitory and antibacterial peptides from Lactobacillus helveticus PR4 proteinase-hydrolyzed caseins of milk from six species. Appl Environ Microbiol (2003) 69(9):5297-305. doi:10.1128/ AEM.69.9.5297-5305.2003

31. Ballard O, Morrow AL. Human milk composition: nutrients and bioactive factors. Pediatr Clin North Am (2013) 60(1):49-74. doi:10.1016/j.pcl.2012. 10.002

32. Chuang C-K, Lin S-P, Lee H-C, Wang T-J, Shih Y-S, Huang F-Y, et al. Free amino acids in full-term and pre-term human milk and infant formula. J Pediatr Gastroenterol Nutr (2005) 40(4):496-500. doi:10.1097/01.MPG. 0000150407.30058.47

33. Holder IA, Boyce ST. Agar well diffusion assay testing of bacterial susceptibility to various antimicrobials in concentrations non-toxic for human cells in culture. Burns (1994) 20(5):426-9. doi:10.1016/0305-4179(94) 90035-3

34. Furtado I, Xavier PCN, Tavares LVM, Alves F, Martins SF, Martins Ade S, et al. Enterococcus faecium and Enterococcus faecalis in blood of newborns with suspected noscomial infection. Revista do Instituto de Medicina Tropical de São Paulo (2014) 56(1):77-80. doi:10.1590/S003646652014000100012

35. Lindberg E, Adlerberth I, Hesselmar B, Saalman R, Strannegård I-L, Åberg N, et al. High rate of transfer of Staphylococcus aureus from parental skin to infant gut flora. J Clin Microbiol (2004) 42(2):530-4. doi:10.1128/ JCM.42.2.530-534.2004

36. Nutrition Committee, Canadian Paediatric Society. Nutrient needs and feeding of premature infants. Nutrition Committee, Canadian Paediatric Society. CMAJ (1995) 152(11):1765-85.

37. Schanler RJ. Fortified human milk: nature's way to feed premature infants. J Hum Lact (1998) 14(1):5-11. doi:10.1177/089033449801400104

38. Griffin TL, Meier PP, Bradford LP, Bigger HR, Engstrom JL. Mothers' performing creamatocrit measures in the NICU: accuracy, reactions, and cost. J Obstet Gynecol Neonatal Nurs (2000) 29(3):249-57. doi:10.1111/j. 1552-6909.2000.tb02046.x

39. Kirsten D, Bradford L. Hindmilk feedings. Neonatal Netw (1999) 18(3):68-70. doi:10.1891/0730-0832.18.3.68

Conflict of Interest Statement: The authors declare that the research was conducted in the absence of any commercial or financial relationships that could be construed as a potential conflict of interest.

The reviewer EF and handling editor declared their shared affiliation.

Copyright (c) 2017 Nielsen, Beverly and Dallas. This is an open-access article distributed under the terms of the Creative Commons Attribution License (CC BY). The use, distribution or reproduction in other forums is permitted, provided the original author(s) or licensor are credited and that the original publication in this journal is cited, in accordance with accepted academic practice. No use, distribution or reproduction is permitted which does not comply with these terms. 